\title{
TEORI HUKUM PANCASILA SEBAGAI SINTESA KONVERGENSI TEORI-TEORI HUKUM DI INDONESIA
}

\author{
Any Farida \\ Ketua Bagian Hukum Internasional, Fakultas Hukum Undaris Ungaran \\ e-mail: any.farida@gmail.com
}

\begin{abstract}
ABSTRAK
Ada tiga teori hukum asli Indonesia yang mewarnai perkembangan kajian dan praktik hukum di Indonesia, baik pemikiran, pembuatan, penerapan maupun pada penegakannya. Tiga teori tersebut adalah Teori Hukum Pembangunan yang dipelopori oleh Mochtar Kusumaatmaja, Teori Hukum Progresif yang digagas oleh Satjipto Rahardjo dan Teori Hukum Integratif yang diusung oleh Romli Atmasasmita. Teori Hukum Pembangunan dalam perkembangannya dikritisi oleh teori Hukum Progresif dan Teori Hukum Integratif yang merekontruksi teori Hukum Pembangunan dan sekaligus Teori Hukum Progresif. Hal ini membuktikan bahwa suatu teori itu dibangun berdasarkan teori-teori yang ada sebelumnya. Teori Hukum Pembangunan, Teori Hukum Progresif dan Teori Hukum Integratif jika ditarik benang merah pada suatu titik konvergensi, maka akan memunculkan Teori Hukum Pancasila sebagai sintesanya. Ketiga teori tersebut semuanya berpijak pada hukum yang hidup (living law) dalam masyarakat dan berdasar pada nilai-nilai yang primodial dari bangsa Indonesia itu sendiri; yaitu nilai-nilai Pancasila sebagai peculiar of social life dan sekaligus sebagai volkgeist.Teori Hukum Pancasila adalah sebuah teori hukum yang mendasarkan pada nilai-nilai Pancasila sebagai landasan ontologis, epistemologis, dan bahkan aksiologisnya.
\end{abstract}

Kata Kunci: Teori Hukum, Pancasila, konvergensi.

\section{ABSTRACT}

Three legal origin theories of Indonesia have influenced the development of study and practice of law in Indonesia, whether in its thought, creation, implementation, and enforcement. Those three theories are Mochtar Kusumaatmadja's Developmental Legal Theory, Satjipto Rahardjo's Progressive Legal Theory and Romli Atmasasmita's Integrative Legal Theory. Developmental Legal Theory has been criticized by Progressive Legal Theory and Integrative Legal Theory which rebuilds both Developmental Legal Theory and Progressive Legal Theory. It proves that a theory is built based on previous theories. Viewing these theories (the Developmental Legal Theory, Progressive Legal Theory and Integrative Legal Theory) from corvergence point generates Legal Theory of Five Principles known as Pancasila. All these theories are based on living law in society and primordial values of Indonesian, which are the values of Pancasila as peculiar of social life and volkgeist. Legal Theory of Pancasila is a legal theory based on the values of Pancasila as ontological, epistemological and axiological foundation.

Keywords: Legal Theory, Pancasila, convergence.

\section{PENDAHULUAN}

Sejak tahun 1970-an sampai sekarang, ada tiga teori hukum asli Indonesia yang mewarnai perkembangan kajian dan praktik hukum di Indonesia, baik pemikiran, pembuatan, penerapan maupun pada penegakannya. Tiga teori tersebut adalah Teori Hukum Pembangunan yang dipelopori oleh Mochtar Kusumaatmaja, Teori Hukum Progresif yang digagas oleh Satjipto Rahardjo, dan Teori Hukum Integratif yang diusung oleh Romli Atmasasmita. Teori Hukum Pembangunan dalam perkembangannya dikritisi oleh Teori Hukum Progresif dan Teori Integratif merekontruksi Teori Hukum Pembangunan dan sekaligus Teori Hukum Progresif. Hal ini 
membuktikan bahwa suatu teori itu dibangun berdasarkan teori-teori yang ada sebelumnya.

Teori Hukum Pembangunan yang dipelopori oleh pakar Hukum Internasional yang pernah menjabat sebagai Menteri Luar Negeri dan Menteri Kehakiman di era Orde Baru ini, dimasukkan sebagai materi hukum dalam naskah Rencana Pembangunan Lima Tahun (Repelita) II pada tahun 1974-1979. Menurut Mochtar, semua masyarakat yang sedang membangun selalu dicirikan dengan perubahan dan hukum berfungsi sebagai penjamin terhadap perubahan yang terjadi secara teratur yang dapat dibantu oleh sebagai suatu sarana (bukan sebagai alat) yang tidak dapat diabaikan dalam proses pembangunan. Hukum yang baik adalah hukum yang sesuai dengan hukum yang hidup atau the living law dalam masyarakat dan sesuai dengan pencerminan dari niali-nilai yang berlaku dalam masyarakat tersebut. ${ }^{1}$

Teori Hukum Pembangunan justru dalam praktik pembentukan dan penegakan hukum masih mengalami hambatan-hambatan yang dikarenakan sulitnya menentukan tujuan dari perkembangan (pembaruan) hukum, yang lebih parah lagi karena adanya upaya destruktif pengambil kebijakan yang kerap mengambil celah untuk menggunakan hukum sekedar sebagai alat dengan tujuan memperkuat dan mendahulukan kepentingan kekuasaan dari pada kepentingan dan manfaat bagi masyarakat. ${ }^{2}$

Realitas atau fakta empirik yang menempatkan hukum sebagai alat justifikasi dasar peraturan, serta telah terjadi fenomena hukum yang menjadikan hukum sebagai saluran untuk menjalankan keputusan politik. Hukum telah menjadi sarana perekayasaan sosial dan juga sarana rekayasa birokrasi. Hal inilah yang menjadikan Satjipto Raharjo memunculkan Teori Hukum Progresif sebagai hukum yang pro rakyat dan pro keadilan dengan asumsi dasar hukum adalah untuk manusia, bukan manusia untuk hukum. Hukum bertugas untuk melayani masyarakat, bukan sebaliknya. Kualitas suatu hukum ditentukan oleh kemampuannya untuk mengabdi pada kesejahteraan rakyat. Hukum itu untuk harga diri, kebahagiaan, kesejahteraan dan kemuliaan manusia, maka setiap kali ada masalah dengan hukum, maka hukumlah yang ditinjau dan diperbaiki bukan manusia yang

\footnotetext{
${ }^{1}$ Romli Atmasasmita, Teori Hukum Integratif: Rekonstruksi terhadap Teori Hukum Pembangunan dan Teori Hukum Progresif, Genta Publishing, Yogyakarta, 2012, h. 65-66.

2 Ibid., h. 77.
}

dipaksakan untuk dimasukkan ke dalam sistem hukum. $^{3}$

Teori Hukum Integratif menurut Romli Atmasasmita merupakan perpaduan antara Teori Hukum Pembangunan dan Teori Hukum Progresif dalam konteks Indonesia yang terinspirasi oleh konsep hukum menurut H.L.A Hart. Hal ini karena Hart menekankan pentingnya rule of recognation dalam konsep hukum dibandingkan dengan primary rules yang menekankan pada kewajiban anggota masyarakat untuk mematuhi undang-undang. ${ }^{4}$ Teori Hukum Integratif menjelaskan bahwa rekayasa birokrasi dan rekayasa masyarakat harus dilandaskan pada sistem norma, sistem perilaku dan sistem nilai yang bersumber pada Pancasila sebagai ideologi bangsa Indonesia.

Jika ditarik benang merah, ketiga teori tersebut; Teori Hukum Pembangunan, Teori Hukum Progresif, dan Teori Hukum Integratif memiliki kecenderungan yang sama, yaitu bahwa hukum hendaknya untuk mencapai kesejahteraan masyarakatnya. Hal ini ketika dikaitkan dengan ke-Indonesia-an, maka pemikiran ketiga teori tersebut dilandaskan pada falsafah bangsa yaitu Pancasila sebagai pandangan hidup, peculiar form of social life dan volkgeist. Oleh karena itu, di kesempatan ini sangat menarik untuk mencermati adanya suatu konvergensi dari ketiga teori hukum tersebut di atas, dan memunculkan serta menegaskan bahwa sebenarnya teori hukum yang tepat untuk bangsa Indonesia adalah Teori Hukum Pancasila sebagai suatu sintesa persoalan-persoalan hukum bangsa dan negara.

\section{PERMASALAHAN}

Dari pemaparan di atas, Teori Hukum yang digagas oleh anak bangsa tersebut jika ditarik suatu titik konvergensi, maka akan memunculkan Teori Hukum Pancasila, bagaimana mengkonvergensikan ketiga teori tersebut dan menjadikan Teori Hukum Pancasila sebagai sintesa dari konvergensi tersebut?

Pembahasan permasalahan ini dilakukan dengan menggunakan metode pendekatan konseptual. Adapun tujuan tulisan ini adalah untuk mengetahui dan menganalisis konvergensi Teori Hukum Pembangunan, Teori Hukum Progresif, dan Teori Hukum Integratif serta menjadikan Teori Hukum Pancasila sebagai sintesa konvergensi tersebut.

\footnotetext{
${ }^{3}$ Ibid., h. 89.

${ }^{4}$ Ibid., h. 97.
} 


\section{PEMBAHASAN}

Teori Hukum menurut Aulis Aarnio seperti yang dikutip oleh Bernard Arief Sidharta merupakan seperangkat pernyataan, pandangan, pengertian yang saling berkaitan secara logikal berkenaan dengan sistem hukum tertentu atau suatu bagian dari sistem tersebut, yang dirumuskan sedemikian rupa sehingga berdasarkannya dimungkinkan untuk merancang hipotesis tentang isi aturan hukum (yakni produk interpretasi aturan hukum) dan konsep yuridik yang terbuka untuk pengujian, berfungsi untuk mensistematisasi kaidah-kaidah hukum dengan caracara tertentu. ${ }^{5}$

Teori Hukum yang didefinisikan di atas, oleh J.J.H. Bruggink disebut sebagai teori hukum dalam arti produk yaitu suatu keseluruhan pernyataan yang saling berkaitan berkenaan dengan sistem konseptual aturan-aturan hukum dan putusan-putusan hukum dan sistem tersebut untuk sebagian yang penting dipositifkan. ${ }^{6}$ Teori Hukum dalam arti produk ini mengacu pada hasil-hasil kegiatan teoritis dalam bidang hukum. Sebaliknya, terdapat teori hukum dalam arti proses, yaitu kegiatan teoritis itu sendiri yang berupa aktivitas pemaknaan atas konsep-konsep hukum, norma hukum, asas-asas hukum, sampai pada nilai-nilai hukum. Seluruh rangkaian ini ditampung dalam suatu cabang disiplin hukum yang disebut teori ilmu hukum. ${ }^{7}$ Teori Hukum dalam arti produk ini adalah suatu teori hukum sebagai pilar keilmuan hukum, sedangkan teori dalam arti proses adalah suatu teori (ilmu) hukum yang menjadi cabang dari disiplin hukum. ${ }^{8}$

Setiap teori termasuk teori hukum mempunyai paling sedikit dua fungsi, yaitu fungsi menjelaskan fenomena dan meramalkan fenomena. Pemahaman ini sejalan dengan pendapat Kerlinger yang menyatakan, Theory is a set of interrelated cunstructs (concepts), definitions, and propositions that present a systematics view of phenomena by specifiying

\footnotetext{
${ }^{5}$ Bernard Arief Sidharta, Ilmu Hukum Indonesia: Upaya Pengembangan Ilmu Hukum Sistematis yang Responsif terhadap Perubahan Masyarakat, Genta Publishing, Yogyakarta, 2013, h. 69.

${ }^{6}$ J.J.H. Bruggink, Refleksi tentang Hukum, terjemahan Bernard Arief Sidharta, Citra Aditya Bakti, Bandung, 1996, h. 160.

${ }^{7}$ Shidarta, Teori Hukum Berstatus Ganda, dalam buku, Pengembangan Hukum Teoritis, Refleksi atas Konstelasi Disiplin Hukum, Logos Publishing, Bandung, 2015, h. 109.

${ }^{8}$ Ibid., h. 110.
}

relations among variables with the purposeof explaining and predicting the phenomena. ${ }^{9}$

Teori Hukum dengan demikian merupakan bagian dari strategi kognisi yang dibangun dari bawah (ranah faktual), digeneralisasi menuju ke konsep, dari konsep direalisasikan ke konsep lain sebagai suatu proposisi-proposisi yang saling berkait dan membentuk kerangka berpikir untuk menjelaskan atau explaining dan memperkirakan atau predicting suatu fenomena. ${ }^{10}$ Sebagai sebuah strategi kognisi maka teori diasumsikan ada (lahir) mendahului suatu ilmu. Setelah ilmu itu terbentuk dan berdiri mapan, ia akan terus memproduksi teori-teori baru atau memodifikasi teori-teori lama. Teori diposisikan sebagai pilar-pilar dari suatu ilmu, sehingga suatu ilmu termasuk ilmu hukum mempunyai teori-teori hukum sebagai penopangnya (pilar).

Suatu teori pada umumnya harus berangkat dari proposisi-proposisi dan konsep-konsep yang bersambungkan dengan fakta, artinya tidak ada teori yang tidak faktual. Inilah yang sebenarnya yang disebut dengan strategi kognisi pembentukan ilmu. Ilustrasi yang bisa digambarkan adalah sebagai berikut: ${ }^{11}$

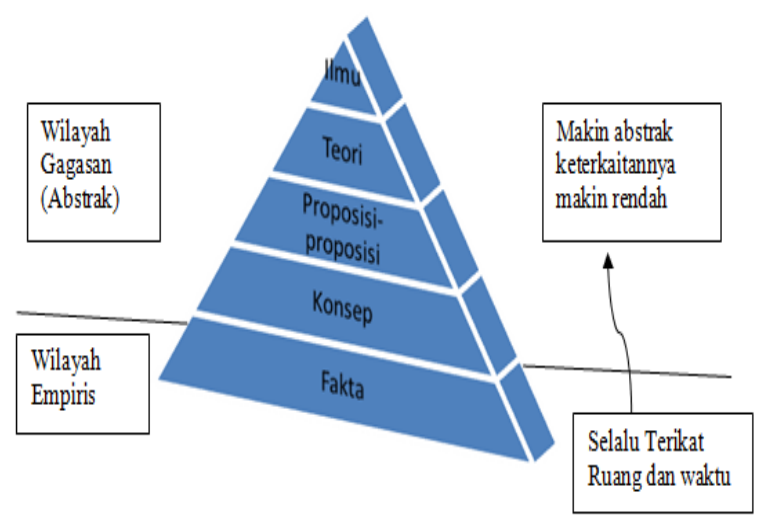

Teori hukum sebagai cabang disiplin hukum merupakan jembatan ilmu hukum dogmatis dan filsafat hukum. Tugas dari teori hukum ini ada tiga, yaitu: pertama, menganalisis dan menerangkan pengertian dari hukum dan konsep-konsep yuridis yang digunakan di dalam hukum; kedua, menjelaskan hubungan antara hukum dan logika, serta ketiga,

\footnotetext{
${ }^{9}$ Ibid., h. 110-111.

${ }^{10} \mathrm{Ibid}$.

${ }^{11}$ Ibid., h. 118.
} 
memberikan dasar filsafat ilmu bagi ilmu hukum dan memberikan ajaran metode bagi praktik hukum. ${ }^{12}$

\section{Teori Hukum Pembangunan}

Untuk memahami Teori Hukum Pembangunan yang diusung oleh Mochtar Kusumaatmadja ini perlu memperhatikan proposisi-proposisi yang sangat penting, berikut ini: ${ }^{13}$

Pertama, Hukum adalah salah satu dari kaidah sosial (di samping kaidah moral, agama, susila, kesopanan, adat kebiasaan dan lain-lain), yang merupakan cerminan dari nilai-nilai yang berlaku dalam masyarakat, sehingga hukum yang baik adalah hukum yang sesuai dengan hukum yang hidup atau living law.

Kedua, Hukum tidak hanya kompleks kaidah dan asas yang mengatur, tetapi juga meliputi lembaga-lembaga dan proses yang diperlukan untuk mewujudkan berlakunya hukum itu dalam kenyataan.

Ketiga, Hukum bercirikan pemaksaan oleh negara melalui alat-alat perlengkapannya, sebab tanpa kekuasaan hukum hanyalah kaidah anjuran; kekuasaan diperlukan demi kehidupan masyarakat yang tertib (teratur); hukum tanpa kekuasaan harus ada batas-batasnya (kekuasaan tanpa hukum adalah kelaliman).

Keempat, Kekuasaan dapat memunculkan wibawa dan bertahan lama jika mendapat dukungan dari pihak yang dikuasai; untuk itu penguasa harus memiliki semangat mengabdi pada kepentingan umum atau sense of public service dan yang dikuasai tunduk pada penguasa atau the duty of civil obedience; keduanya harus dididik agar memiliki kesadaran kepentingan umum atau public spirit.

Kelima, Tujuan pokok dan pertama dari segala hukum adalah ketertiban, yang merupakan syarat fundamental bagi adanya suatu masyarakat yang teratur; untuk tercapainya ketertiban diperlukan kepastian dalam pergaulan antar manusia dalam masyarakat; tujuan kedua setelah ketertiban adalah keadilan yang isi keadilan ini berbeda-beda menurut masyarakat dan zamannya.

${ }^{12}$ D.H.M. Mewissen, Tentang Pengembangan Hukum, Ilmu Hukum, Teori Hukum, dan Filsafat Hukum, terjemahan Bernard Arief Sidharta, Refika Adiatma, Bandung, 2007, h. 27 dan 31.

${ }^{13}$ Sidharta, Posisi Pemikiran Teori Hukum Pembangunan dalam Konfigurasi Aliran Pemikiran Hukum (Sebuah Diagnosis Awal), dalam Mochtar Kusumaatmadja dan Teori Hukum Pembangunan, Eksistensi dan Implikasi, Jakarta, Epistema Institute, 2012, h. 19-22.
Keenam, Masyarakat Indonesia sedang dalam masa peralihan (transisi) dari tertutup menuju terbuka, dinamis, dan maju (modern); hakikat masalah pembangunan adalah pembaruan cara berpikir (sikap, sifat, nilai-nilai), baik pada penguasa maupun yang dikuasai, misalnya pada anggota masyarakat harus berubah dari sekedar bersikap mental sebagai kaula (kawula-jawa) negara menjadi sikap mental sebagai warga negara (tidak hanya pasif mengikuti perintah penguasa tetapi juga aktif mengetahui bahkan berani menuntut hak-haknya).

Ketujuh, Dalam masyarakat yang sedang membangun, hukum tidak cukup hanya bersifat memelihara dan mempertahankan yang telah dicapai (sifat konservatif dari hukum) tetapi juga berperan merekayasa masyarakat; namun intinya tetap harus ada ketertiban (selama perubahan dilakukan dengan cara yang tertib, selama itu masih ada tempat bagi peranan hukum).

Kedelapan, Pembangunan harus dimaknai seluas-luasnya meliputi segala segi dari kehidupan masyarakat dan tidak hanya segi kehidupan ekonomi belaka.

Kesembilan, Hukum sebagai alat pembaruan dalam masyarakat yang sedang membangun itu dapat pula merugikan, sehingga harus dilakukan berhati-hati; oleh sebab itu penggunaan hukum harus dikaitkan juga dengan segi-segi sosiologi, antropologi dan kebudayaan; ahli hukum dalam masyarakat yang sedang membangun perlu mempelajari hukum positif dengan spektrum ilmu-ilmu sosial dan budaya.

Kesepuluh, Peranan hukum dalam pembangunan adalah untuk menjamin bahwa perubahan itu terjadi dengan cara yang teratur (tertib); hukum berperan melalui bantuan perundang-undangan dan keputusan pengadilan atau kombinasi dari keduanya; namun pembentukan perundang-undangan adalah cara yang paling rasional dan cepat dibandingkan dengan cara pengembangan hukum lain seperti yurisprudensi dan hukum kebiasaan.

Kesebelas, Kendala atau kesukaran yang dihadapi dalam rangka berperannya hukum dalam pembangunan; a. sukarnya menentukan tujuan perkembangan (pembaruan) hukum; b. sedikitnya data empiris yang dapat digunakan untuk mengadakan suatu analisis deskriptif dan prediktif; c. sukarnya mengadakan ukuran yang objektif tentang berhasil tidaknya usaha pembaruan hukum; d. adanya kepemimpinan yang kharismatis yang kebanyakan 
kepentingannya bertentangan dengan cita-cita legal engineering menuju suatu masyarakat atau negara hukum; e. masih rendahnya kepercayaan dan keseganan terhadap hukum atau respect for the law dan peranannya dalam masyarakat, khususnya bagi masyarakat yang lahir melalui keguncangan politik (revolusi); f. reaksi masyarakat karena menganggap perubahan itu bisa melukai kebanggaan nasional; $g$. reaksi yang berdasarkan salah diri, yaitu golongan intelektualnya sendiri tidak mempraktikkan nilai atau sifat yang mereka anjurkan; h. heterogenitas masyarakat Indonesia, baik dari segi tingkat kemajuan, agama, bahasa, dan lain-lain.

Keduabelas, Dalam rangka pembentukan perundang-undangan dalam era Indonesia yang sedang membangun perlu diprioritaskan yaitu pembentukan peraturan perundanga-undangan di bidang-bidang hukum yang netral (tidak sensitif). Ranah hukum yang demikian praktis tidak akan banyak menimbulkan kontroversi terkait dengan adat istiadat, agama, dan niali-nilai primordial lainnya.

Proposisi-proposisi tersebut dibangun di atas teori kebudayaan dari Northrop, Teori Orientasi Kebijaksanaan atau policy-oriented dari Mc. Dougal dan Laswell dan Teori Hukum Pragmatis dari Roscoe Pound. Menurut Mochtar, hukum merupakan keseluruhan asas-asas dan kaidah-kaidah yang mengatur kehidupan manusia dalam masyarakat, juga mencakup lembaga-lembaga atau institutions, proses-proses atau processes yang mewujudkan berlakunya kaidah-kaidah itu dalam kenyataan. Pengertian tersebut menunjukkan bahwa Teori Hukum Pembangunan ini diperkuat oleh teori-teori tersebut di atas, yaitu hukum bukan sekedar norma melainkan juga institusi atau dari Teori Kebudayaan Northrop, dan kepekaan hukum terhadap kondisi dan gejala-gejala kemasyarakatan dan fungsi hukum sebagai sarana pembangunan merupakan sumbangan penting dari Eugen Ehrlich dan Roscoe Pound yang berasal dari aliran hukum pragmatis. ${ }^{14}$ Teori Hukum Pembangunan Mochtar merupakan transformasi dari teori hukumnya sendiri, ditambah dengan transformasi dari teori Roscoe Pound. Mochtar menolak konsepsi mekanis dari konsepsi "law as tool of social engineering" dan menggantikan istilah alat atau tool dengan istilah sarana. ${ }^{15}$ Jika digambarkan

14 Lili Rasjidi, Hukum sebagai Suatu Sistem, Remaja Rosdakarya, Bandung, 1993, h. 126.

15 Ibid. dengan bagan, Teori Hukum Pembangunan sebagai berikut: ${ }^{16}$

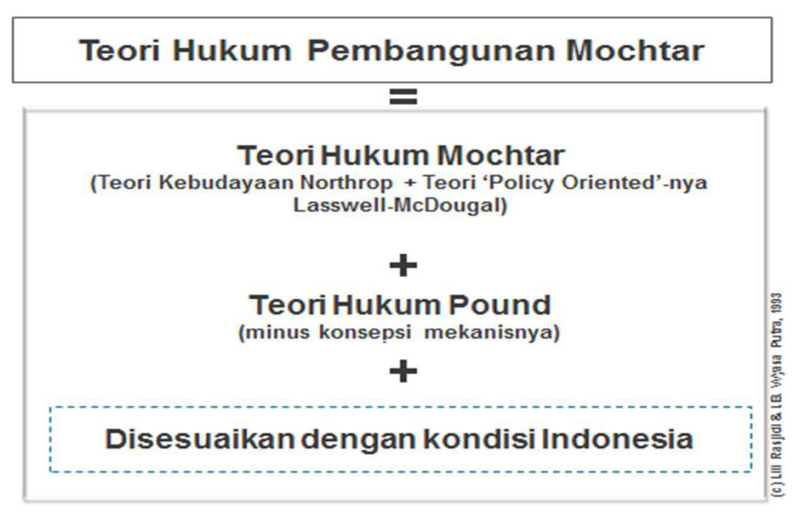

Paparan di atas merupakan pendiskripsian Teori Hukum Pembangunan fase pertama, fase kedua dari teori ini mendasarkan teori dengan filsafat Pancasila sebagai landasan fundamental untuk menggantikan teori-teori dari Northrop, Eugen Ehrlich, Roscoe Pound, Mc. Dougal dan Laswell. Istilah-istilah seperti cita hukum Pancasila, filsafat hukum Pancasila, dan negara hukum Pancasila mulai diwacanakan. Tujuan dari hukum pada umumnya adalah ketertiban dan keadilan. Tujuan keadilan ini mencakup di dalamnya keadilan sosial (sila kelima Pancasila). Persoalan manusia Indonesia di dalam pembangunan di dasarkan pada asumsi penerimaan Pancasila dan UUD 1945 sebagai suatu kenyataan dan landasan berpikir dan bertindak manusia Indonesia. ${ }^{17}$

\section{Teori Hukum Progresif}

Teori Hukum Progresif yang diusung oleh Satjipto Raharjo dapat dimengerti lewat postulatpostulat seperti di bawah ini: ${ }^{18}$

Pertama, Hukum progresif itu untuk manusia, bukan manusia untuk hukum. Pada hakikatnya setiap manusia itu baik, sehingga sifat ini layak menjadi modal dalam membangun kehidupan berhukumnya.

16 Shidarta, Teori Hukum Integratif dalam Konstelasi Pemikiran Filsafat Hukum (Interpretasi atas Sebuah "Teori Rekonstruksi", dalam Shidarta's Articles, diunduh dari http:// shidarta-articles.blogspot.co.id/2012/05/teori-hukum-integratifdalam-konstelasi.html, diakses tanggal 15 Desember 2015, jam 20.25 WIB.

${ }^{17}$ Sidharta, Posisi Pemikiran Teori Hukum Pembangunan dalam Konfigurasi Aliran Pemikiran Hukum (Sebuah Diagnosis Awal), Op.Cit., h. 23.

${ }^{18}$ Shidarta, Posisi Pemikiran Hukum Progresif dalam Konfigurasi Aliran-aliran Filsafat Hukum: Sebuah Diagnosis Awal, dalam buku Satjipto Raharjo dan Hukum Progresif Urgensi dan Kritik, Epistema Institute, Jakarta, 2011, h. 55-58. 
Hukum bukan raja (segalanya), tetapi sekedar alat bagi manusia untuk memberi rahmat kepada dunia dan kemanusiaan. Hukum tidak untuk dirinya sendiri, tetapi untuk sesuatu yang lebih luas dan lebih besar. Oleh karenanya, jika ada masalah dalam dan dengan hukum, maka hukumlah yang harus ditinjau dan diperbaiki, bukan manusia yang dipaksa-paksa untuk dimasukkan ke dalam skema hukum. Sistem hukum perlu diletakkan dalam alur besar atau deep-ecology, maka pemikiran di atas dapat dieja sebagai hukum untuk konteks kehidupan sejagat, di mana manusia bukan lagi titik sentral satu-satunya.

Kedua, Hukum progresif itu harus pro rakyat dan pro keadilan. Hukum itu harus berpihak kepada rakyat. Keadilan harus didudukkan di atas peraturan. Para penegak hukum harus berani menerobos kekakuan teks peraturan - yang diistilahkan dengan mobilisasi hukum-jika memang teks itu mencederai rasa keadilan rakyat. Prinsip pro rakyat dan pro keadilan ini merupakan ukuran-ukuran untuk menghindari agar progresivisme ini tidak mengalami kemerosotan, penyelewengan, penyalahgunaan dan hal negatif lainnya.

Ketiga, Hukum progresif bertujuan mengantarkan manusia kepada kesejahteraan dan kebahagiaan. Hukum harus memikili tujuan lebih jauh dari pada yang diajukan oleh falsafah liberal. Pada falsafah pasca liberal, hukum harus menyejahterakan dan membahagiakan. Hal ini sejalan dengan cara pandang orang Timur yang memberikan pengutamaan pada kebahagiaan.

Keempat, Hukum progresif selalu dalam proses menjadi atau law as a process, law in the making. Hukum bukan institusi yang final, melainkan ditentukan oleh kemampuannya mengabdi kepada manusia. Ia terus-menerus membangun dan mengubah dirinya menuju ke tingkat kesempurnaan yang lebih baik. Setiap tahap dalam perjalanan hukum adalah putusan-putusan yang dibuat guna mencapai ideal hukum, baik yang dilakukan legislatif, yudikatif maupun eksekutif. Setiap putusan bersifat terminal menuju kepada putusan berikutnya yang lebih baik. Hukum tidak pernah bisa meminggirkan sama sekali kekuatan-kekuatan otonom masyarakat untuk mengatur ketertibannya sendiri. Kekuatan-kekuatan tersebut akan selalu ada, sekalipun dalam bentuk terpendam (laten). Pada saat-saat tertentu ia akan muncul dan mengambil alih pekerjaan yang tidak bisa diselesaikan dengan baik oleh hukum negara. Oleh karena itu, sebaiknya memang hukum itu dibiarkan mengalir saja.

Kelima, Hukum progresif menekankan hidup baik sebagai dasar hukum yang baik. Dasar hukum terletak pada perilaku bangsanya sendiri, karena perilaku bangsa itulah yang menentukan kualitas berhukum bangsa tersebut. Fundamen hukum tidak terletak pada bahan hukum atau legal stuff, sistem hukum, berfikir hukum dan sebagainya, melainkan lebih pada manusia atau perilaku manusia. Di tangan perilaku buruk, sistem hukum akan menjadi rusak, tetapi tidak di tangan orang baik, sistem hukum akan menjadi baik.

Keenam, Hukum progresif memiliki responsif. Dalam tipe responsif, hukum akan selalu dikaitkan pada tujuan-tujuan di luar narasi tekstual hukum itu sendiri yang disebut oleh Nonet dan Selznick sebagai the souvereingnity of purpose. Pendapat ini sekaligus mengkritik doktrin due process of law. Tipe responsif menolak otonomi hukum yang bersifat final dan tidak dapat digugat.

Ketujuh, Hukum progresif mendorong peran publik. Mengingat hukum mempunyai kemampuan yang terbatas, maka mempercayakan segala sesuatu kepada kekuatan hukum adalah sikap yang tidak realistis dan keliru. Di sisi lain, masyarakat ternyata memiliki kekuatan otonom untuk melindungi dan menata dirinya sendiri. Kekuatan ini untuk sementara tenggelam di bawah dominasi hukum modern yang notabene adalah hukum negara. Untuk itu, hukum progresif sepakat memobilisasi kekuatan otonom masyarakat atau mendorong peran publik.

Kedelapan, Hukum progresif membangun negara hukum yang berhati nurani. Dalam bernegara hukum yang utama adalah kultur, the culture primacy. Kultur yang dimaksudkan adalah kultur pembahagiaan rakyat. Keadaan tersebut dapat dicapai apabila kita tidak berkutat pada the legal stucture of state melainkan harus lebih mengutamakan a state with conscien. Dalam bentuk pertanyaan hal tersebut akan berbunyi “bernegara hukum untuk apa?" dan dijawab dengan "bernegara hukum untuk membahagiakan rakyat".

Kesembilan, Hukum progresif dijalankan dengan kecerdasan spiritual. Kecerdasan spiritual tidak ingin dibatasi patokan atau rule-bound, juga tidak hanya bersifat kontekstual, tetapi ingin keluar dari situasi yang ada dan mencari kebenaran makna atau nilai yang lebih dalam. 
Kesepuluh, Hukum progresif itu merobohkan, mengganti, dan membebaskan. Hukum progresif menolak sikap status quo dan submisive. Sikap status quo menyebabkan kita tak berani melakukan perubahan dan menganggap doktrin sebagai sesuatu yang mutlak untuk dilaksanakan. Sikap tersebut hanya merujuk kepada maksim 'rakyat untuk hukum'.

Sama dengan teori-teori lain Teori Hukum Progresif ini juga dibangun berdekatan atau berbagi dengan aliran pemikiran dan teori-teori yang lain, diantaranya adalah: aliran hukum kodrat yang terlihat pada peletakan dasar hukum, yaitu nilai keadilan dan kemanusiaan; madzhab sejarah pada pemikiran bahwa hukum merupakan pencerminan dari masyarakatnya (peculiar form of social life) atau social specific; interessenjurisprudenz (the jurisprudence of interest) bahwa hukum (undang-undang) dibuat dengan tujuan tertentu yaitu the general purpose of society; sociological jurisprudence pada titik singgung bahwa studi hukum tidak hanya tentang peraturanperaturan, tetapi juga terhadap efek hukum serta bekerjanya hukum; realisme hukum-freirechtslehre tidak melihat hukum pada hukum itu sendiri, malainkan dari tujuan sosial yang ingin dicapai dan akibat-akibat dari bekerjanya hukum; Critical Legal Studies, titik temunya pada kritik keduanya terhadap sistem hukum liberal yang didasarkan pada pikiran politik liberal, khususnya terkait dengan rule of law serta keberpihakan hukum kepada rakyat melalui affirmative action; Teori Hukum Responsif bahwa hukum progresif adalah hukum berproses yang tidak selayaknya tunduk terhadap suatu batasan tertentu, dan hukum dibiarkan mengalir.

\section{Teori Hukum Integratif}

Teori ini disusun berangkat dari sikap skeptis masyarakat terhadap penanganan perkara hukum di Indonesia, dengan kesimpulan bahwa kaum praktisi hukum telah melupakan dan mengabaikan nilai-nilai luhur Pancasila sebagai ideologi bangsa dan terjebak pada 'kontrak normatif' yang telah diwariskan oleh aliran Kelsenian. Teori Hukum Integratif ini terinspirasi oleh Posner dalam bukunya Frontiers of Legal Theory yang menyatakan bahwa teori hukum ini menggunakan perspektif eksternal disiplin hukum. ${ }^{19}$ Teori ini diklaim didasarkan juga pada pemikiran teori sebelumnya yaitu Teori Hukum Pembangunan dan Teori Hukum Progresif, bahkan Romli Atmasasmita

\footnotetext{
${ }^{19}$ Romli Atmasasmita, Op.Cit, h. 7.
}

menyebut teorinya ini sebagai Teori Pembangunan Jilid II. ${ }^{20}$ Oleh karenanya, Teori Hukum Integratif ini bertitik tolak dari Teori Hukum Pembangunan jilid I oleh Mohtar Kusumaatmadja yang mempunyai butir-butir pemikiran yang sama. Dari pemikiran yang dibangun oleh teori hukum pembangunan ini menelaah pada upaya penyeimbangan antara hukum positif atau law in the books dan hukum yang hidup atau living law. Fungsi hukum dengan demikian mengarah pada sarana social order atau sebagai fungsi paling konservatif dari hukum, sekaligus sebagai sarana social engineering. Ini berarti, pada tahap yang paling awal, hukum wajib mengarah pada pencapaian ketertiban sebagai syarat, menuju keadaan kepastian dan keadilan. Teori ini menempatkan keadilan sebagai tujuan paling ideal, sekalipun makna keadilan bisa sangat beragam, semua diarahkan pada keberhasilan pembangunan nasional dalam konteks (sosial) keindonesiaan. ${ }^{21}$

Teori Hukum Integratif ini menyatakan bahwa hukum pada hakikatnya terdiri dari tiga unsur yaitu sistem norma, prilaku dan nilai yang disebut dengan tripartite character of indonesian legal theory of social and bureaucratic engineering. ${ }^{22}$ Persoalan tentang siapa yang menjadi "motor" dalam pengembangan hukum atau rechtsbeoefening, menjadi salah satu kunci penting dalam Teori Hukum Integratif. Mengacu pendapat Mochtar bahwa pembentukan hukum atau perundang-undangan adalah cara yang paling rasional dan cepat dibanding dengan metode pengembangan hukum lain seperti yurisprudensi dan hukum kebiasaan. Artinya, bahwa pembentuk undang-undang memiliki posisi sebagai 'motor'. Namun demikian Mochtar juga melihat arti penting yurisprudensi dan hukum kebiasaan sebagai sumber hukum formal, tetapi tidak pernah memposisikan yurisprudensi dan hukum kebiasan sebagai suatu kriteria sebagai peraturan perundang-undangan. Lompatan teori hukum integratif ini menyarankan bahwa sistem hukum Indonesia seharusnya memasukkan yurisprudensi sebagai salah satu unsur dalam struktur atau hierarkhi perundang-undangan. ${ }^{23}$ Teori hukum integratif menyatakan bahwa pendekatan

${ }^{20}$ Ibid., h. 85-86.

21 Shidarta, Teori Hukum Integratif dalam Konstelasi Pemikiran Filsafat Hukum (Interpretasi atas sebuah "Teori Rekonstruksi”, Op.Cit.

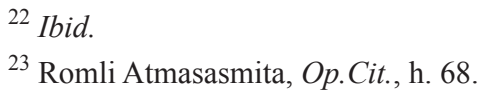


bureaucratic and social engineering menggunakan konsep "panutan" dan "kepemimpinan". ${ }^{24}$ Oleh karenanya, birokrat dan hakim merupakan "motor" dalam hukum. Rekayasa birokrasi berkaitan dengan sistem norma dan perilaku akan efektif jika berfondasikan penanaman nilai-nilai. Norma hukum adalah konkretisasi dari nilai-nilai itu, yang pada gilirannya diejawantahkan melalui perilaku. Artinya, baik sistem norma (hukum positif) maupun sistem perilaku tetap perlu direkayasa agar sarat dengan nilai-nilai yang antara lain harus bermuatan Pancasila.

\section{Teori Hukum Pancasila}

Ketiga teori tersebut di atas jika ditarik benang merah pada suatu titik konvergensi, maka akan memunculkan Teori Hukum Pancasila sebagai sintesanya. Dari Teori Hukum Pembangunan, Teori Hukum Progresif, dan Teori Hukum Integratif semuanya berpijak pada hukum yang hidup atau living law dalam masyarakat dan berdasar pada nilai-nilai yang primodial dari bangsa Indonesia itu sendiri yaitu, nilai-nilai Pancasila sebagi peculiar of social life dan sekaligus sebagai volkgeist. Teori Hukum Pancasila adalah sebuah teori hukum yang mendasarkan pada nilai-nilai Pancasila sebagai landasan ontologis, epistemologis dan bahkan aksiologisnya. Hukum sebagai suatu produk (struktur hukum) harus berdasarkan pada asas-asas hukum. Asas-asas hukum Pancasila antara lain: ${ }^{25}$

Pertama, Asas ketuhanan, mengamanatkan bahwa tidak boleh ada produk hukum yang bertentangan, menolak atau pun bermusuhan dengan agama maupun kepercayaan terhadap Tuhan Yang Maha Esa; Kedua, Asas perikemanusiaan, mengamanatkan bahwa hukum harus melindungi warga negara dan menjunjung tinggi harkat martabat manusia; Ketiga, Asas kesatuan dan persatuan atau kebangsaan, bahwa hukum Indonesia harus merupakan hukum yang mempersatukan kehidupan berbangsa dengan menghormati keragaman dan kekayaan budaya bangsa; Keempat, Asas demokrasi, mendasarkan bahwa hubungan antara hukum dan kekuasaan, kekuasaan harus tunduk terhadap hukum bukan sebaliknya. Sistem demokrasi harus dilandasi

${ }^{24}$ Ibid., h. 83.

${ }^{25}$ Mochtar Kusumaatmadja dan Bernard Arief Sidharta, Pengantar Ilmu Hukum: Suatu Pengenalan Pertama Ruang Lingkup Berlakunya Ilmu Hukum, Buku I, Alumni, Bandung, 1999, h. 137-139. nilai permusyawaratan, kebijaksanaan dan hikmah; Kelima, Asas keadilan sosial, bahwa semua warga negara mempunyai hak dan kewajiban yang sama di depan hukum.

Di samping itu, Pancasila menjadi sangat aksiomatik dan juga ilmiah dalam ukuran kesepakatan kolektif bangsa Indonesia. Kelima sila Pancasila membentuk serangkaian sistem ideologis, filosofis yang logik saintifik sebagai dasar hukum utama yang menempatkannya sebagai grundnorm, sehingga merupakan sumber dari segala sumber hukum. ${ }^{26}$

Pancasila sebagai suatu sistem filsafat pada hakikatnya bersifat organis, yaitu merupakan satu kesatuan dari sila-silanya. Kelima sila tersebut merupakan suatu asas peradaban dasar filsafat negara dan bangsa Indonesia. Sila-sila Pancasila itu merupakan suatu kesatuan dan keutuhan, yaitu setiap sila merupakan unsur (bagian yang mutlak) dari Pancasila. Oleh karenanya, Pancasila merupakan kesatuan yang majemuk tunggal. Konsekuensinya setiap sila tidak dapat berdiri sendiri-sendiri terlepas dari sila-sila yang lainnya, dan tidak saling bertentangan. ${ }^{27}$ Secara filosofis Pancasila sebagai suatu kesatuan sistem filsafat memiliki dasar ontologis, epistemologis, dan aksiologis sendiri yang berbeda dengan sistem filsafat yang lainnya, misalnya materialisme, liberalisme, pragmatisme, komiunisme, dan lain-lain sistem filsafat di dunia.

Dasar ontologis Pancasila pada hakikatnya adalah manusia yang memiliki hakikat mutlak monopluralis yang memiliki unsur-unsur susunan kodrat jasmanirohani, sifat kodrat individu-makhluk sosial dan kedudukan kodrat sebagai pribadi yang berdiri sendiri-makhluk Tuhan Yang Maha Esa. Unsur-unsur hakikat manusia tersebut merupakan satu kesatuan yang bersifat organis dan harmonis. Setiap unsur mempunyai fungsi masing-masing namun saling berhubungan. Oleh karenanya, sila-sila Pancasila merupakan penjelmaan hakikat manusia monopluralis yang merupakan kesatuan organis, sehingga sila-sila Pancasila juga memiliki kesatuan yang bersifat organis pula. Subyek pendukung pokok sila-sila Pancasila adalah manusia, dengan penjelasan bahwa; yang berketuhanan Yang Maha Esa, berkemanusiaan yang

${ }^{26}$ Prasetijo Rijadi dan Sri Priyati, Membangun Ilmu Hukum Mazhab Pancasila, dalam Buku Memahami Hukum dari Konstruksi sampai Implementasi, Raja Grafindo Persada, Jakarta, 2011, h. 33.

${ }^{27}$ Ibid., h. 58. 
adil dan beradab, berpersatuan, berkerakyatan yang dipimpin oleh hikmah dalam kebijaksanaan dalam permusyawaratan/perwakilan, serta berkeadilan sosial pada hakikatnya adalah manusia. ${ }^{28}$

Dasar epistemologis Pancasila pada hakikatnya tidak dapat dipisahkan dari dasar ontologisnya, yaitu hakikat manusia. Ada tiga persoalan mendasar yang muncul dalam dasar epistemologis yaitu, pertama tentang sumber pengetahuan manusia, kedua tentang teori kebenaran pengetahuan manusia dan ketiga tentang watak pengetahuan manusia. ${ }^{29}$ Persoalan epistemologi dalam hubungannya dengan Pancasila dapat dijelaskan sebagai berikut: Menurut Notonegoro dalam skema potensi rokhaniah manusia terutama dalam kaitannya dengan pengetahuan akal manusia merupakan sumber daya cipta manusia dan dalam upaya untuk memperoleh pengetahuan yang benar terdapat tingkat-tingkat pemikiran yaitu; memoris, reseptif, kritis, dan kreatif. Adapun daya atau potensi untuk meresapkan atau mentransformasikan pengetahuan terdapat tingkatan sebagai berikut; demonstrasi, imajinasi, asosiasi, analogi, refleksi, intuisi, inspirasi dan ilham. Berdasarkan tingkatan tersebut, maka Pancasila mengakui kebenaran rasio yang bersumber pada akal manusia. Selain itu manusia memiliki indra sehingga dalam proses reseptif indra merupakan alat untuk mendapatkan kebenaran pengetahuan yang bersifat empiris, maka Pancasila juga mengakui kebenaran empiris terutama pengetahuan manusia yang bersifat positif. Selain itu Pancasila juga mengakui kebenaran pengetahuan yang bersumber pada intuisi. Kedudukan manusia menurut kodratnya adalah makhluk Tuhan Yang Maha Esa, maka sesuai dengan sila pertama, maka epistemologis Pancasila juga mengakui kebenaran wahyu (kebenaran profetik) yang bersifat mutlak sebagai tingkatan kebenaran yang tertinggi. Kebenaran dalam pengetahuan manusia adalah suatu sintesa yang harmonis antara potensi-potensi kejiwaan manusia yaitu, akal, rasa, dan kehendak manusia untuk mendapatkan kebenaran yang tertinggi yaitu kebenaran mutlak. Sebagai paham epistemologi Pancasila mendasarkan pandangannya bahwa ilmu pengetahuan pada hakikatnya tidak bebas nilai

${ }^{28}$ Notonegoro dalam Kaelan, Pendidikan Pancasila, Paradigma, Yogyakarta, 2010, h. 62.

${ }^{29}$ Titus Harold H., Marlyn S. Smith, Richart T. Nolan dalam Living Issues Philosophy, diterjemahkan oleh HM Rasyidi, yang dikutip oleh Kaelan, Ibid., h. 67. karena harus diletakkan pada kerangka moralitas kodrat manusia serta moralitas religius dalam upaya untuk mendapatkan satu tingkatan pengetahuan yang mutlak dalam hidup manusia. ${ }^{30}$

Dasar aksiologis Pancasila menjelaskan bahwa sila-sila sebagai suatu sistem filsafat juga memiliki satu kesatuan dasar aksiologisnya, sehingga nilainilai yang terkandung dalam Pancasila pada hakikatnya juga merupakan satu kesatuan. Nilainilai yang terkandung dalam Pancasila termasuk nilai kerohanian yang didalamnya terkandung nilainilai lain secara lengkap dan harmonis, baik nilai material, vital, kebenaran (kenyataan), estetis, etis dan relegius. Adapun nilai-nilai tersebut tersusun secara hierarkis adalah nilai ketuhanan sebagai nilai tertinggi, kemudian nilai kemanusiaan, nilai persatuan, nilai kerakyatan dan nilai keadilan. Nilainilai tersebut meski memiliki tingkat dan luas yang berbeda-beda namun keseluruhannya merupakan satu kesatuan dan tidak saling bertentangan. Pada pelaksanaan atau realisasinya dalam kehidupan sehari-hari bermasyarakat, berbangsa dan bernegara, misalnya dalam suatu perundang-undangan maka nilai ketuhanan adalah nilai tertinggi dan bersifat mutlak, oleh karenanya hukum positif atau perundangundangan tidak boleh bertentangan dengan nilai ketuhanan. ${ }^{31}$

Kedudukan Pancasila sebagai filsafat menurut Abubakar Busro dapat ditinjau dari tiga kenyataan, yakni: kenyataan materiil, dari jangkauan dan isinya bersifat nilai-nilai fundamental, universal, komprehensif dan metafisis bahkan pokok pengajarannya meliputi nilai-nilai keagamaan dan kemanusiaan; kenyataan fungsional praktis, merupakan jalinan tata nilai dalam sosio-budaya bangsa Indonesia sehingga wujudnya dapat dilihat adanya prinsip kepercayaan kepada Tuhan, tepa selira, setia kawan, kekeluargaan, gotong royong, musyawarah mufakat, dan lain-lain; dan kenyataan formal (para pendiri negara mengangkat dan merumuskan Pancasila sebagai ideologi yang wujudnya tampak dalam Pembukaan UUD 1945 sebagai dasar Negara Kesatuan Republik Indonesia. ${ }^{32}$

\footnotetext{
${ }^{30}$ Ibid., h. 69-70.

${ }^{31}$ Ibid., h. 70-76.

${ }^{32}$ Agus Budi Susilo, "Penegakan Hukum yang Berkeadilan dalam Perspektif Filsafat Hermeneutika Hukum, Suatu Alternatif Solusi terhadap Penegakan Hukum di Indonesia”, Jurnal Perspektif, Vol. XVI No. 4 Tahun 2011 Edisi September, h. 247.
} 


\section{PENUTUP}

\section{Kesimpulan}

Teori Hukum Pembangunan, Teori Hukum Progresif, dan Teori Hukum Integratif jika ditarik benang merah pada suatu titik konvergensi, maka akan memunculkan Teori Hukum Pancasila sebagai sintesanya, ketiga teori tersebut semuanya berpijak pada hukum yang hidup atau living law dalam masyarakat dan berdasar pada nilai-nilai yang primodial dari bangsa Indonesia itu sendiri yaitu, nilai-nilai Pancasila sebagai peculiar of social life dan sekaligus sebagai volkgeist. Teori Hukum Pancasila adalah sebuah teori hukum yang mendasarkan pada nilai-nilai Pancasila sebagai landasan ontologis, epistemologis dan bahkan aksiologisnya.

\section{Rekomendasi}

Dalam pembuatan, penegakan, dan penerapan hukum diharapkan berpijak pada Teori Hukum Pancasila.

\section{DAFTAR PUSTAKA}

Absori, Kelik Wardiono dan Saepul Rohman, 2015, Hukum Profetik Kritik terhadap Paradigma Hukum Non-Sistemik, Yogyakarta: Genta Publishing.

Atmasasmita, Romli, 2012, Teori Hukum Integratif: Rekonstruksi terhadap Teori Hukum Pembangunan dan Teori Hukum Progresif, Yogyakarta: Genta Publishing.

Bruggink, J.J.H., 1996, Refleksi tentang Hukum, terjemahan Bernard Arief Sidharta, Bandung: Citra Aditya Bakti.

Kaelan, 2010, Pendidikan Pancasila, Yogyakarta: Paradigma.

Mewissen, D.H.M., 2007, Tentang Pengembagnan Hukum, Ilmu Hukum, Teori Hukum, dan Filsafat Hukum, terjemahan Bernard Arief Sidharta, Bandung: Refika Adiatma.
Rasjidi, Lili, 1993, Hukum sebagai Suatu Sistem, Bandung: Remaja Rosdakarya.

Rijadi, Prasetijo dan Sri Priyati, 2011, Membangun Ilmu Hukum Mazhab Pancasila, dalam Buku Memahami Hukum dari Konstruksi sampai Implementasi, Jakarta: Raja Grafindo Persada.

Sidharta, Bernard Arief, 2011, Posisi Pemikiran Hukum Progresif dalam Konfigurasi Aliranaliran Filsafat Hukum: Sebuah Diagnosis Awal, dalam buku Satjipto Raharjo dan Hukum Progresif Urgensi dan Kritik, Jakarta: Epistema Institute.

, 2012, Posisi Pemikiran Teori Hukum Pembangunan dalam Konfigurasi Aliran Pemikiran Hukum (Sebuah Diagnosis Awal), dalam Mochtar Kusumaatmadja dan Teori Hukum Pembangunan, Eksistensi dan Implikasi, Jakarta: Epistema Institute. , 2013, Ilmu Hukum Indonesia: Upaya Pengembangan Ilmu Hukum sistematis yang Responsif terhadap Perubahan Masyarakat, Yogyakarta: Genta Publishing. , Teori Hukum Berstatus Ganda, dalam Buku Pengembanan Hukum Teoritis, Refleksi atas Konstelasi Disiplin Hukum, Bandung: Logos Publishing, 2015. , Teori Hukum Integratif dalam Konstelasi Pemikiran Filsafat Hukum (Interpretasi atas sebuah "Teori Rekonstruksi", dalam Shidarta's Articles, diunduh dari http://shidarta-articles. blogspot.co.id/2012/05/teori-hukum-integratifdalam-konstelasi.html, diakses tanggal 15 Desember 2015 jam 20.25 WIB.

Susilo, Agus Budi, "Penegakan Hukum yang Berkeadilan dalam Perspektif Filsafat Hermeneutika Hukum, Suatu Alternatif Solusi terhadap Penegakan Hukum di Indonesia”, Jurnal Perspektif, Vol. XVI No. 4 Tahun 2011 Edisi September. 